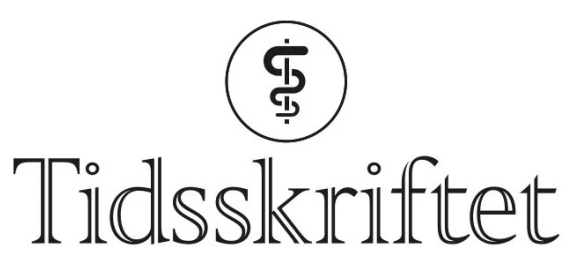

DEN NORSKE LEGEFORENING

\title{
Rettelse: De sultet seg for å hjelpe andre
}

RETTELSE

\section{LASSE BANG}

$\varnothing Y$ VIND R $\varnothing$

Tidsskr Nor Legeforen 2021; 141: 988-92.

I Tidsskriftet nr. 10/2021, s. 991 skal det stå: I 2018 ble det publisert en oppfølgingsstudie basert på intervjuer fra starten av 20oo-tallet, da de gjenlevende deltakerne var 70-80 år. Alle utenom én sa at de ville deltatt i sult-studien igjen.

Vi beklager feilen, den er rettet på nett.

Publisert:30. august 2021. Tidsskr Nor Legeforen. DOI: 10.4045/tidsskr.21.0575

(C) Tidsskrift for Den norske legeforening 2023. Lastet ned fra tidsskriftet.no 26. april 2023. 